\title{
Traditional Knowledge on Teff (Eragrostistef) Farming Practice and Role of Crop Rotation to Enrich Plant Growth Promoting Microbes for Soil Fertility in East Showa: Ethiopia
}

\author{
Birhanu Gizaw*, ZerihunTsegay, Genene Tefera,Endegena Aynalem, Endeshaw Abatneh and Getasew Amsalu \\ Microbial Biodiversity Directorate, Ethiopian Biodiversity Institute, Ethiopia
}

Submission: March 30, 2018; Published: June 22, 2018

"Corresponding author: Birhanu Gizaw, Microbial Biodiversity Directorate, Ethiopian Biodiversity Institute, Ethiopia, Tel: +251911862561; Email. gizachewbirhan@gmail.com

\begin{abstract}
Teff (Eragrostis tef) supports more than 60-75\% of Ethiopia's population as staple and co-staple food. Interest in teff has increased noticeably due to its very attractive nutritional profile and gluten-free nature of the grain. Teff farming practice varies in different growing areas. Study objective was to assess and document farmer's traditional knowledge of teff farming and utilization practice. Data was collected using structured, semi-structured questionnaire from 172 listed elder informants. Teff farming steps and farming area preparation, cultivated teff variety, the role of crop rotation, type of agroforestry, traditional threshing, type of crop used for rotations, role of microbes in soil fertility, farming equipment, storage and piling practice were described. Among the respondents $91.86 \%$ were male and $8.14 \%$ female. Teff variety currently cultivated by many farmers are Magna, Sergegna, Bunign, kuncho, Qoreta, Bost, Package, Oromia, Shenkore, Cross37, Kora. 96\% of respondent used cop rotation for teff farming and productivity. These are Lathyrus sativus, Phaseolusvulgaris, Pistum stvium, Lensculinaris, Cicer arietinum, Zeamays, Triticum aestivum, Hordeum vulgare, Allium cepa, Trigonella foenum-graecum. Teff productivity differed in the type of crop used for rotation, in average $3000 \mathrm{Kg} /$ hectar, $2625 \mathrm{Kg} /$ hektar, $2230 \mathrm{Kg} /$ hektar, $1700-2000 \mathrm{Kg} /$ hektar is obtained from crop rotated by Onion, Common bean, Chickpea and Lentil respectively. This traditional knowledge in using of legume \& cereal plant for crop rotation in teff productivity confirms that farmers indirectly enrich plant growth promoting microbes. These are, Acinetobacter, Agrobacterium, Bacillus, Burkholderia, Chryseomonas, Enterobacter, Pseudomonas, Rhizobium spp. involved in Nitrogen fixation, phosphate solubilization, Phytohormon, sidrophore and Antibiotics production.
\end{abstract}

Keywords: Crop rotation; Chick pea; Microbs; Pea; Teff; PGPR; Vetch

\section{Introduction}

Farmers have a wealth of indigenous knowledge on crop production in their communities acquired through accumulation of experience and, informal experiment that could be useful for a robust crop breeding program, agriculture mechanization, modernization of farming equipment, improve grain quality and storage equipment, designing weed and pest control strategies, organic seed conservation, food preparation, education and training, environmental conservation [1]. Teff based farming system is an indigenous and sustainable agricultural system in Ethiopia [2]. According to Nicolai Vavilov, teff originated and was domesticated in Ethiopia between 4000-1000BC [3]. Teff (Eragrostis tef), a cereal grain that is included grass family of Poaceae, and endemic and diversified to Ethiopia and it has been widely produced for many centuries [4]. Within the genus Eragrostis $43 \%$ of the species seem to have originated in Africa, $18 \%$ in South America, 12\% in Asia, 10\% in Australia, 9\% in
Central America, 6\% in North America and 2\% in Europe [5]. Of the 54 Eragrostis species listed in Ethiopia, 14 (or 26\%) are endemic [6]. Teff is a self-pollinated, annual, warm season grass that is used throughout the world as grain for human consumption and as forage for livestock. Teff grain is found widely in most part of the country mainly grown under diverse agro-ecological conditions in the altitude ranging from 1800 to 2100 meters above sea level. The major Teff producing areas are Amhara, Oromia, Tigray and South nation and nationality regional people of Ethiopia. In Ethiopia there are several varieties of teff, each unique to specific growing condition $[7,8]$ describes three main types of teff grain, white, brown and mixed (brown and white), Teff is adapted and distributed in a wide range of environment even in marginal soils [9]. About 2,730,272.95 hectares of land is assumed to be covered by teff in the country [10]. Teff is grown mainly in Amhara and Oromiya, which 
together accounted for 84 and 86 percent of the total cultivated area and production in 2011. East and West Gojam of Amhara and East and West Shoa of Oromiya region are particularly known teff producing areas in the country [10]. East Gojjam is the leading zone in Teff production constituting more than 10 percent of the national annual Teff production [11]. Teff supports more than $60-75 \%$ of Ethiopia's population as staple food and believed as a traditional medicine especially for diabetic people in many areas of the country. Teff is also quite high in energy, fat content $2.6 \%$, Protein content $8 \%$ to $15 \%$ (with an average of $11 \%$ ). While the vitamin content is about average compared to other cereals, the fermentation process of making injera generates additional vitamins, further enhancing the value of the grain. In addition, the mineral content shows especially good values for iron and calcium. Teff does not contain gluten and is therefore a promising alternative for those suffering from coeliac disease or other forms of low gluten tolerance. Teff is highly nutritious and is an important part of Ethiopia's cultural heritage and national identity. Being labeled as one of the latest super foods of the 21st century, like the ancient Andean grain quinoa, teff's international popularity is rapidly growing [12]. Teff is a very important crop in Ethiopia, both in terms of production and consumption. In a country of nearly 90 million people, approximately 6 million households grow teff [13]. Ethiopian farmers grow this crop for a number of merits, which is mainly attributed to the socioeconomic, cultural and agronomic benefits. Indigenous knowledge is a store of experience and awareness of native society on technologies, practices and beliefs that forms the basis for production of different crops $[14,15]$. Although teff became high value and socially important crop for Ethiopian culture, information on local indigenous knowledge on crop rotation and soil fertility increament on production and yield improvement as well as management and cultivar selection criteria of farmers is insufficient or not documented properly, and, hence, the attributes are less known by the scientific community. Such knowledge needs to be fully explored and documented for use by researchers. Thus, detailed analysis of farmers' indigenous knowledge on production and management system with their selection criteria has tremendous contribution for cultivar development; improved management practices and develops teff genetic resources conservation strategies, as well as bio fertilizer development for present and future generation. This study was therefore designed to search valid and reliable information for assessing and documenting farmers traditional knowledge on Teff farming practice and the role of crop rotation in plant growth promoting microbes enhancement for soil fertility in East showa zone, Ethiopia.

\section{Materials and Methods}

\section{The study area description}

The study was conducted in Ethiopia, Oromia regional state, East Shewa Zone. It has 12 districts according to the zonal statistics and information center, East Shewa is found between $38^{\circ} 57^{\prime}$ and $39^{\circ} 32^{\prime} \mathrm{E}$ and $7^{\circ} 12^{\prime}$ and $9^{\circ} 14^{\prime} \mathrm{N}$. $93 \%$ of the district falls in the lowlands in rift valley. The average altitude is 1600 $\mathrm{m}$, but rises up to $2300 \mathrm{~m}$ at the north western and western mountain fringes of the rift on one hand, and it falls to 900$1000 \mathrm{~m}$ towards northeast. Agro ecology of the zone is divided in to three, $0.2 \%$ area of the zone is found in the high land, $61.1 \%$ midland and the rest $38.7 \%$ is found in the low land. Specifically this study was conducted in Boset, Lome, Adama, Ada'a, Gimbichu districts (Figure 1).

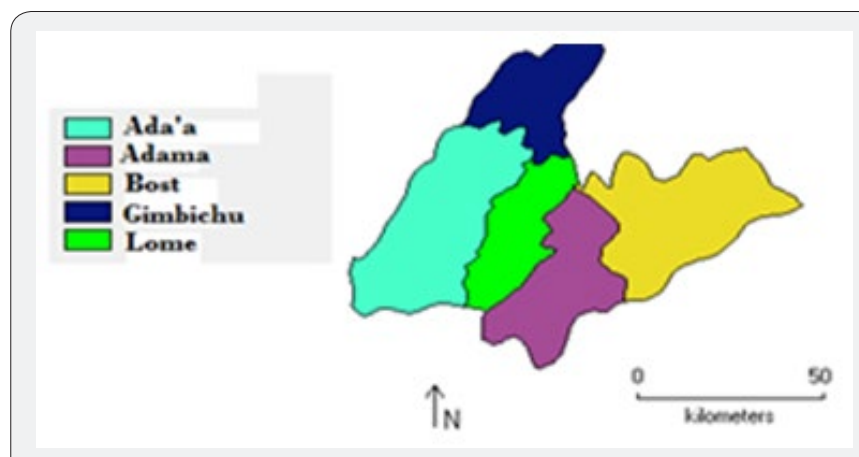

Figure 1: Map of study area

\section{Selection of participating households}

Selection of respondent was made on meeting with district agricultural experts and key informants familiar about the Teff farming. 172 teff producing households were selected from six districts and 21 kebels of East shewa zone. The study Kebeles (the smallest administrative unit in Ethiopia) were selected purposively based on their agro ecology, soil type, teff production potential and Teff variety. Elders whose age are 20 and above were purposively used with different socioeconomic back grounds in the study and their detail information were recorded.

\section{Data collection}

In order to document and assess farmers traditional knowledge on Teff farming and utilization practice both primary and secondary data were collected. Structured and semistructured questionnaire was designed to collect information across the 172 listed elder informants. Both interviews in the village and questionnaires were filled. Secondary data was obtained from the agricultural office of the district, from different books, journal and research article. The questionnaires mainly focused on informants socio demographic characteristics and experience on their traditional knowledge of Teff farming practice and utilization, role of crop rotation in soil fertility improvement, role of microbes during crop rotation, types of crop during rotation, equipment used for Teff farming, Teff variety and seed selection criteria, Teff storage practice, the role of microorganism for teff productivity, The role of gender perception in Teff farming and management. Accordingly, about $10 \%$ of elderly traditional resourceful inhabitants (158 males \& 14 females) of the kebele were identified and interviewed to solicit their local knowledge on Teff farming and utilization practice. The sample size was determined by following procedure and then questioners were collected from 172 target adult individuals [12]. 


\section{Statistical analysis}

The data analysis involved various descriptive statistics such as means and percentages frequency. For each questionnaire, the percentage of farmers who gave similar response was calculated. The summarized variables include, sex, household size, educational status age structure, land holding size and other variable data were analyzed using SPSS ver 23.

\section{Result and Discussion}

\section{Socio-economic characteristics of the selected households (Socio demographic Data)}

The study covered 43 group informants having 172 adult individuals in east showa zone. From all study participants 8.14\% were females and $91.86 \%$ were males. The higher proportion of male gender may possibly the farmers interviewed during the active plough period. The age groups of interviewed farmers were ranges; 0-20 years (3.49\%), followed by 21-30 years $(29.06 \%), 31-40$ years $(31.4 \%)$ and $41-50$ years $(10.47 \%)$, and above 50 years old (25.58\%). In general, $63.95 \%$ of the population involved in the study was the age in between $0-40$ years old, while the rest of $36.05 \%$ were the ages greater than 40 years old. With regard to ethnic group majority of study participants (99.9\%) are Oromo ethnic groups, With regards to educational backgrounds $36.04 \%$ of the respondents were illiterate and $55.84 \%$ completed primary school, $5.81 \%$ of the respondents were secondary school, In relation to family size $34.88 \%$ of the respondent has $1-3$ family numbers, $44.19 \%$ has 4 to 6 family numbers, $19.77 \%$ has $7-9$ family numbers and 1.16 $\%$ has above 10 family numbers. With regards to income source of farmers, $62.8 \%$ depend only Teff farming, $24.42 \%$ depend on both Teff farming and animal rearing, $8.14 \%$ their income depend on renting their farmland and trade. In terms of their Teff farm size $39.53 \%$ farmers have less than one hectare farm land, and $34.88 \%$ more than one hectare farmland. Table 1 summarizes all socio demographic data.

Table 1: Socio demographic Data of the study area.

\begin{tabular}{|c|c|c|c|c|c|c|c|c|c|}
\hline Item & Description & Boset & Adama & Adaa & Lumme & Gimbichu & Ejere & Frequency & Percentage \\
\hline \multirow{2}{*}{ Sex } & M & 14 & 18 & 62 & 40 & 8 & 16 & 158 & 91.86 \\
\hline & $\mathrm{F}$ & 4 & 2 & 2 & 6 & 0 & 0 & 14 & 8.14 \\
\hline \multirow{5}{*}{ Age } & $0-20$ & 0 & 0 & 4 & 0 & 0 & 2 & 6 & 3.49 \\
\hline & $21-30$ & 6 & 6 & 14 & 14 & 6 & 4 & 50 & 29.06 \\
\hline & $31-40$ & 6 & 10 & 20 & 10 & 2 & 6 & 54 & 31.4 \\
\hline & $41-50$ & 4 & 2 & 8 & 4 & 0 & 0 & 18 & 10.47 \\
\hline & Above 50 & 2 & 2 & 18 & 18 & 0 & 4 & 44 & 25.58 \\
\hline \multirow{6}{*}{ Education } & Illiterate & 2 & 4 & 12 & 28 & 2 & 4 & 62 & 36.04 \\
\hline & 01-Jun & 10 & 12 & 24 & 10 & 0 & 10 & 66 & 38.4 \\
\hline & 07-Aug & 4 & 4 & 14 & 4 & 2 & 2 & 30 & 17.44 \\
\hline & 09-Dec & 0 & 0 & 2 & 4 & 4 & 0 & 10 & 5.81 \\
\hline & College & 0 & 0 & 0 & 0 & 0 & 0 & 0 & 0 \\
\hline & University & 2 & 0 & 2 & 0 & 0 & 0 & 4 & 2.33 \\
\hline \multirow{4}{*}{ Family size } & $1-3 \mathrm{HH}$ & 12 & 4 & 14 & 12 & 8 & 10 & 60 & 34.88 \\
\hline & $4-6 \mathrm{HH}$ & 6 & 12 & 28 & 24 & 0 & 6 & 76 & 44.19 \\
\hline & 7-9HH & 0 & 4 & 20 & 10 & 0 & 0 & 34 & 19.77 \\
\hline & Above 10 & 0 & 0 & 2 & 0 & 0 & 0 & 2 & 1.16 \\
\hline \multirow{5}{*}{ Income source } & Farming & 12 & 10 & 46 & 24 & 2 & 14 & 108 & 62.8 \\
\hline & Rearing & 0 & 0 & 2 & 0 & 0 & 0 & 2 & 1.16 \\
\hline & Farm+Animal rearing & 0 & 8 & 12 & 20 & 2 & 0 & 42 & 24.42 \\
\hline & Farm+Trade & 4 & 2 & 2 & 2 & 4 & 0 & 14 & 8.14 \\
\hline & Other & 2 & 0 & 2 & 0 & 0 & 2 & 6 & 3.49 \\
\hline \multirow{5}{*}{ Farm size } & Less than 1 hectar & 8 & 8 & 24 & 14 & 4 & 10 & 68 & 39.53 \\
\hline & 1 hectare & 6 & 4 & 8 & 8 & 2 & 0 & 28 & 16.28 \\
\hline & 1-2 hectare & 0 & 4 & 4 & 0 & 0 & 6 & 14 & 8.14 \\
\hline & Above 1 hectare & 4 & 4 & 28 & 22 & 2 & 0 & 60 & 34.88 \\
\hline & Rent & 0 & 0 & 0 & 2 & 0 & 0 & 2 & 1.16 \\
\hline
\end{tabular}




\section{Respondent house hold distribution}

A total of 172 informants from 6 districts and 21 kebele were participated in this study and $86.05 \%$ of questioners were collected from midland and lowland area depending on the agro ecology distribution of East showa zone. $0.2 \%$ area of the zone is found in the high land, $61.1 \%$ midland and the rest $38.7 \%$ is found in the low land. High teff varity and teff farming practice also very high at midland and lowland. Therefore large number of respondents was $37 \%$ from Adaa district and least respondent, $4.7 \%$ were from Gimbichu districts (Table 2). A proportional allocation formula was employed to select respondents from each sample kebeles and each farmer's category. $n=N / 1+N(e)^{2}$. (Where: Ni- The total household heads in each Kebele. $\mathrm{N}-$ The total household heads in the sample Kebele. n- Sample size of households in the study area).

Table 2: Frequency and percentage distribution of sampled household per districts.

\begin{tabular}{|c|c|c|c|c|}
\hline S.No. & District & Kebele & Frequency & Percentage \\
\hline 1 & Boset & Gere, Digelo,Teri-Beriti & 18 & 10.47 \\
\hline 2 & Adama & Dabi soleke, Didibesana wachulafa, GurjaFurda & 20 & 11.63 \\
\hline 3 & Adaa & Malimo,Chelba,Dire,Hidi, Mintlae & 64 & 37.21 \\
\hline 4 & Lomme & Tulureae,TiltiGerbi,Dekabora,Dingugi,Ejersa Joro,Bika,koka & 46 & 26.74 \\
\hline 5 & Gimbichu & HabruMitae,AdadiGulae, & 8 & 4.65 \\
\hline 6 & Ejere & Ejere & 16 & 9.3 \\
\hline & Total sampled Household & & $\mathbf{1 7 2}$ & $\mathbf{1 0 0}$ \\
\hline
\end{tabular}

\section{Land use and agriculture}

The term 'land use' implies the way the people allocate the land for their satisfaction of needs. Farming, grazing, national parks and sanctuaries, construction spaces, etc. are some of the major examples of land uses. As the zonal statistics and information center presented total area of the Zone is estimated to be about $979,907 \mathrm{~km}^{2}$ which is divided for various purposes as stated in study area (Table 3).

Table 3: Land use types of study area.

\begin{tabular}{|c|c|c|c|}
\hline $\mathbf{S} / \mathbf{N}$ & Land Use Types & $\mathbf{K m}^{\mathbf{2}}$ & Percentage \\
\hline 1 & Cultivation land & $4,40,958$ & 45 \\
\hline 2 & Bush and Forest land & $1,56,785$ & 16 \\
\hline 3 & Grazing land & 88,191 & 9 \\
\hline 4 & Water bodies & 48995 & 5 \\
\hline 5 & Settlement area & 224976 & 25 \\
\hline & Total area & $9,79,907$ & 100 \\
\hline
\end{tabular}

The role of gender in teff farming practice and management

In study districts men are the main responsible for tasks of land preparation, repeated ploughing and thining mostly up to 3-5 times, teff cultivation, cutting (Acheda) and threshing, while female farmers are responsible cleaning fields locally known as gulgualo, Awudima (preparation of threshing site), weeding, and pulling of thorns over sowed seed in the absence of rain to cover the seed by soil. Teff seed cleaning is carried out at different stages, right after threshing of the crop are men tasks and at a later stage just before planting using homemade tools (sefed and wonfit) is women's task. Winnowing at threshing time is done by men, a two-stage process, first threshed tef grain is separated from the rough straw and secondly, grain is further purified by wind from fine straw, inert materials, shriveled or broken seeds using wooden tools (layda). Men are responsible for this works and sometimes females are also involved. A study was made in predominantly teff growing areas of Adaa, Lomme and Gimbichu districts of the central highlands of Ethiopia in 1997. It was observed the role of women in tef production was observed during weeding, harvesting, transporting, threshing and storage. Preparation of teff for food is accepted in the study district as a woman's job [16]. It is noted that over 50-80 percent of the labour force required in crop, livestock production as well as in environmental rehabilitation is provided by female farmers in rural Ethiopia and elsewhere in the world [16]. In the Ethiopian context, in general females are actively involved in the following farming activities, though the degree of their involvement might vary due to various reasons such as traditional/ religious influence and type of farming system. Seed cleaning, land preparation called Gulgualo, sowing/planting, weeding and applying manure, hoeing, scaring of birds, harvesting, preparation of threshing fields (includes provision of dung, water and smearing the ground), collection and pilling, winnowing, storing of produce and care of stored seeds, food preparation for labour assistance or hired laborers in the field. Most of the post-harvest operations done by female not well quantified such as cleaning, milling or taking to the milling plants, preparation and baking of food for the family. The gender pattern of labour utilization is often referred to as the triple roles of gender. These are productive, reproductive and community management roles.. The main source of labour is the family, which includes the wife and the children.

\section{Farmer's awareness about local Teff variety and the lost varity from thier farm land}

In Ethiopia there are several varieties of teff, each unique to specific growing condition [17]. Of the 54 Eragrostis species listed in Ethiopia, 14 (or 26\%) are endemic [18]. Thirty four named Ethiopian teff cultivars based on morphological characteristics was described [19]. 95\% of respondent in the 
study districts do have awareness about local teff variety, However Respondent were asked about the lost teff variety from their farmland because of improved variety released, climatic change, soil retardation and deformity, and other market need, and several reasons. One teff variety called, Hadho teff (Enatit) variety were lost from farmland in the study district mentioned by $95 \%$ respondents. The same variety may have different names in different areas and languages. The so called lost Hadho (Enatit) teff variety only referring in the study district and evidence from respondent response only.

\section{Currently cultivated teff variety in east showa}

In the study area there are 13 improved and local variety currently cultivated by farmers locally called, Qoreta, Magna, Oromia, Package, Kuncho, Boset, kora, Shenkore, Kiros, Dagim, Gemechis, Sergegna, Bunign, In the highland above 2000.s.l, Bunign teff was dominant, in mid altitude Qoreta, Kuncho, magna, kora was dominant and Package, Bost and Oromia teff was dominant in low altitude (Figure 2 \& Table 4). Most of the Ethiopian farmers use local varieties of Teff and these are distributed all over the country. Local varieties such as Gea Lamie, Dabi, Shewa Gimira, Beten and Bunign, The same varieties are also used in areas with adequate rainfall and where double cropping is practiced. In the highly productive and major Teff producing regions of Gojam and Shewa, and in other regions where environmental stress is not severe, the local varieties such as Alba, Ada and Enatit are used. Modern varieties are used in many regions but in very small areas within each region. The yield of the modern varities is estimated to be $1700-2200 \mathrm{~kg}$ per hectare on farmers' fields and $2200-2800 \mathrm{~kg}$ per hectare on research managed large farms [11]. Different teff variety cultivated in different part of Ethiopia, for instance West Belessa district of North western Ethiopia,locally called 14 teff varity Awra tef, Boset, Bunign, Dima, Dukem, Etsub, Gemechis, Kuncho, Magna, Mechare, Simada, Tseday, Yilmana, Zobel are cultivated [20].
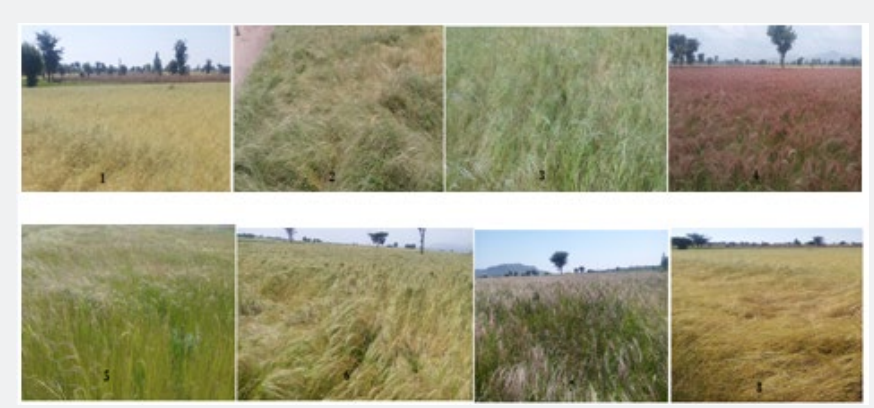

Figure 2: Some of cultivated teff varity 1. Package 2. Red teff 3. Qoreta 4. Kora 5. Bunigne 6. Kuncho 7. Magna 8. Bost.

Table 4: Currently Cultivated Teff variety in East showa

\begin{tabular}{|c|c|c|c|c|}
\hline & Districts & Sampled Kebele & Currently Cultivated Teff In the Study Area & Altitude \\
\hline 1 & Boset & Gere, Tri beriti, Digelo & Qoreta, Magna,Kuncho,keyteff, Oromia,Package & $1200-1500$ m.a.s.l \\
\hline 2 & Adama & Dabi soloqe,Didibsanawachulafa,,Gurja furda & $\begin{array}{c}\text { Kuncho,Gemechis,,kiros(Cross),Qoreta,Magna,keyteff. } \\
\text { Kuncho,,Bost,shenkorae,bunigne }\end{array}$ & $1300-1600$ m.a.s.l \\
\hline 3 & Adaa & Dire, Cheleba,Hidi,Mintilae,Malimo & Kuncho, Bost,Magna,keyteff,kora,Dagim & $1600-2350 \mathrm{~m} . a . s . l$ \\
\hline 4 & Lommae & $\begin{array}{c}\text { Tulureae,TiltiGerbi,Akabora,Dingugi,Ejersa } \\
\text { Joro,Bika,koka }\end{array}$ & $\begin{array}{c}\text { Bost,Kuncho,Kiross,Kora,Segegna,Magna,, Dagim } \\
1500-2150\end{array}$ \\
\hline 5 & Gimbichu & HabruMitae,AdadiGulae, & Kuncho,Shenkorae, Magna,Kora,Bunigne & $2300-2400 \mathrm{~m}$. a.s.l \\
\hline
\end{tabular}

\section{Farmer teff selection criteria}

From study area $85 \%$ respondant in lowland area prefere Bost teff variety for productivity that able to give $1500-2200 \mathrm{Kg} /$ hektar compared to other teff variety however in mid land area $87 \%$ also preferer kuncho teff in its quality for straw, quality of teff grain that became very white and markate sale demands and other stress resistant quality, on diverse soil growing quality. $13 \%$ of repondant prefer teff variety according to locally avilable teff seed where good product is obtaind from previous year.

\section{Traditional equipment for teff farming}

Farmers in East showa used different traditional equipment for teff farming activities almost the same to other area. For ploughing purpose they used different traditional equipment called with their local language, these are, Maresha, Mofer, Kenber Manqya, Eirf, Miran, Digir, wogel, Giraf (Figure 3). Farmers plough for 3 to 5 times for thinning. In low land area around Bost and Adama different kebel they are pulling acacia thorns over the soil to cover sowed seed, if there is no rain on that day. This practice may be unique from other farming practice like Gojam area and North showa [21]. Sometimes used animal walking on ploughed farm. Teff collection practice is mostly common from other area. $100 \%$ of respond cut teff using iron sickle. Sorting grain from straw by using, layida, mensh. and sweeping threshing ground with different grass and acacia thorns. Ploughing is mostly done using pair of oxen (Figure 4). 


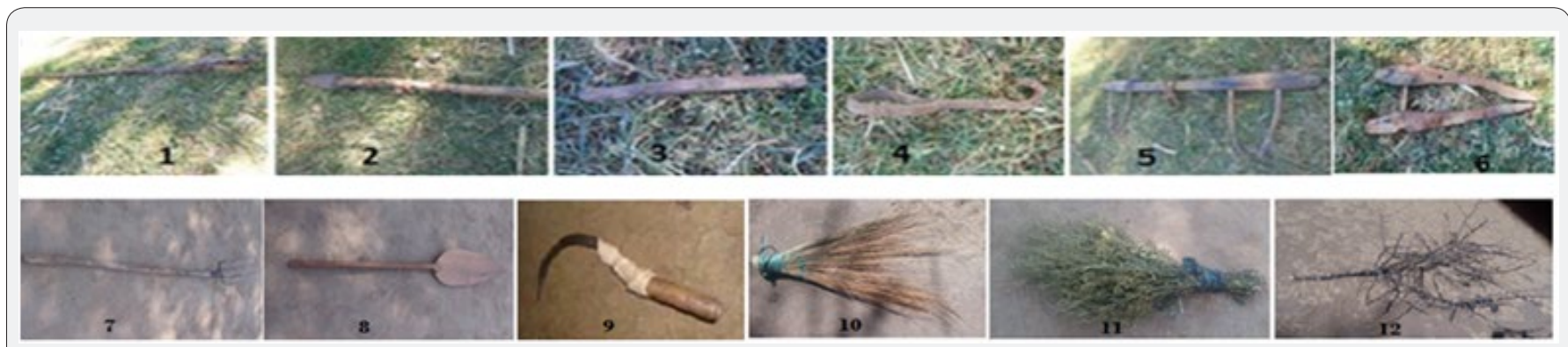

Figure 3: Some of traditional ploughing equipment 1. Mofer 2. Maresha 3. Miran 4. Wogel 5. Kenber 6. Erif 7. Mensh. 8. Layda 9 sickle $10 \& 11$ sweeping materials 12 . Acacia thorns.

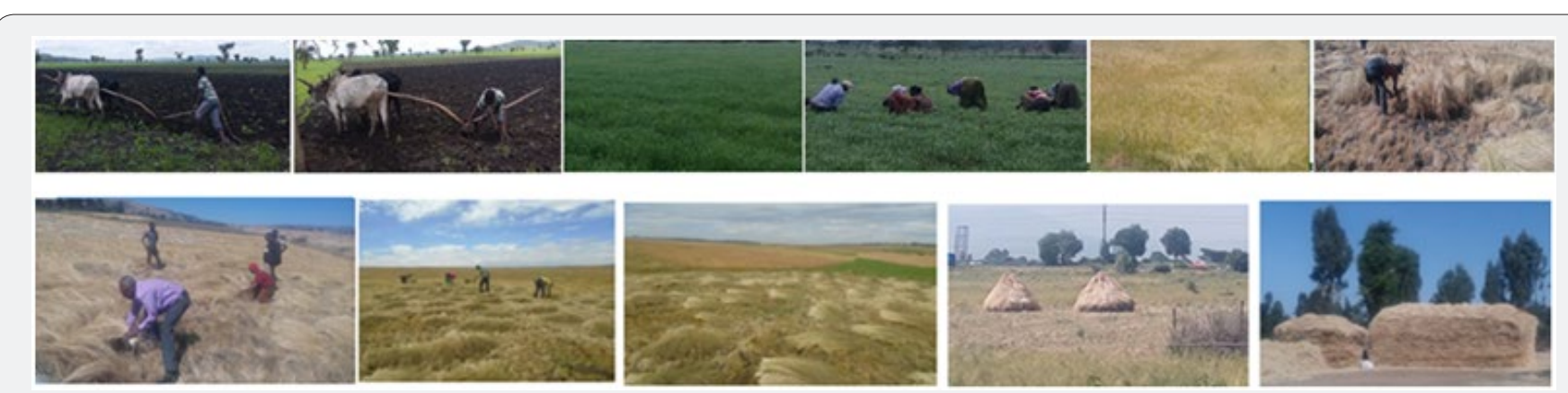

Figure 4: Ploughing, weed picking, Teff cutting, collection and pilling in teff farming activities.

\section{Teff threshing practice}

In the study area $100 \%$ harvesting remains done by hand, with the cut grain often stacked for up to two months before threshing .Threshing is done after all crops have been gathered from the field. The threshing ground is prepared first. A threshing ground called Awdemma is made on nearly level or gently sloping ground by digging out the vegetation inside the soil and smoothing the ground. The tradtional threshing remains mostly done by animal trampling, which leave up to $30 \%$ of the crop on the ground and contaminates the remainder with urine and feces that could reduce the market value. This is a major area that innovations might be possible to improve the grain recovery and reduce the drudgery. Then it has to be winnowed by lyda and Mensh until the grain sorted from straw (Figure 5).

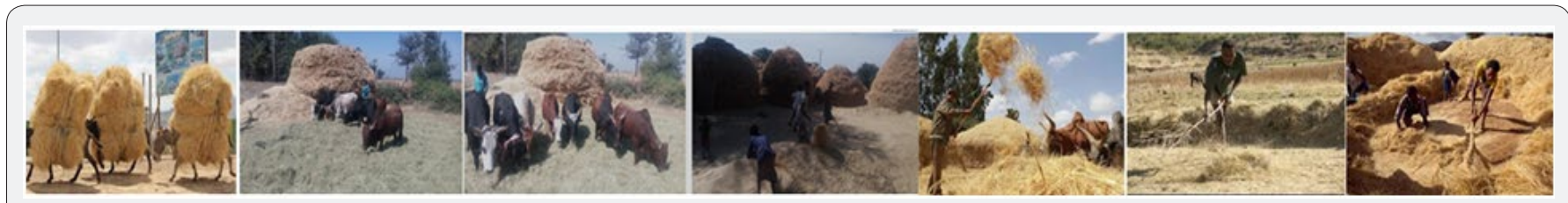

Figure 5: Tradtional teff threshing activities

\section{Traditional knowledge on Teff piling}

In many traditional crop harvesting systems of Ethiopian farmers leave their harvested teff in the field for a long time. Because they wait it until for the threshing. Because they want to pre dry the straw. In this "field drying", the teff plants are often stacked in piles with the panicles inside to protect them from rain, birds and rat. Different shape and arrangement of teff pilling was seen in the study area. In addition to that farmers gave different reasons of teff piling which is summarized in Table 5 \& Figure 6.
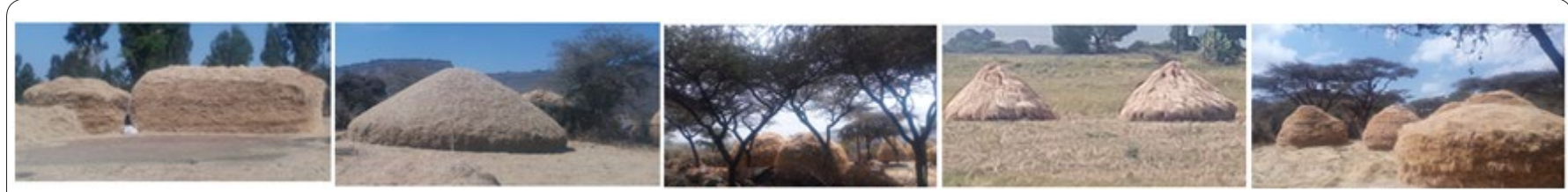

Figure 6: Traditional teff pile practice in different shape and arrangement 
Table 5: Reason for Teff pile

\begin{tabular}{|c|c|c|c|}
\hline & Reason for Teff pile & Respondant & Percentage \\
\hline 1 & Injera gloss increase & 45 & 26.16 \\
\hline 2 & Size and mass of Teff increased & 39 & 22.67 \\
\hline 3 & Injera flavor become good & 29 & 16.86 \\
\hline 4 & Whiteness of Injera color increase & 24 & 13.95 \\
\hline 5 & Rain,bird and rats protection & 19 & 11.05 \\
\hline 6 & Marketability increase & 16 & 9.30 \\
\hline
\end{tabular}

\section{Traditional knowledge on Teff storage}

All respondent in the study area told that tef grain can be stored for an extended period of time 3-5 years under traditional storage conditions in the previous time. Teff grian is not attacked by weevils or fungi, resistant to any granary insect/pests which are serious problems for other cereals that reduce postharvest costs, as no protective chemicals are required for storage [22]. Respondents in the study area were using silo (gottara) before a long period of time, currently ninety percent of respondents stop using Gottera and temporarily collect teff in plastic sacks until market sale and in some district temporarily store in Dibignit (Figure 7). The best way of storing teff grains was the traditional storage method in gota or gottera. The gottera is made up of local materials such as wood, mud, teff straw and wood bark fiber. In northern Ethiopia gottera looks like a small house and varies in its size depending upon the farmer's ability and wealth. Big gottera can contain up to 14 chinet or 7 dawula which is about $800 \mathrm{~kg}$. A rich farmer can own up to 6 gottara where he stores not only teff but also other major crops. Most Amhara region in different districts usually stores his grains in big gota, dibignit, slicha or in sacks at home [21] (Figure 7).

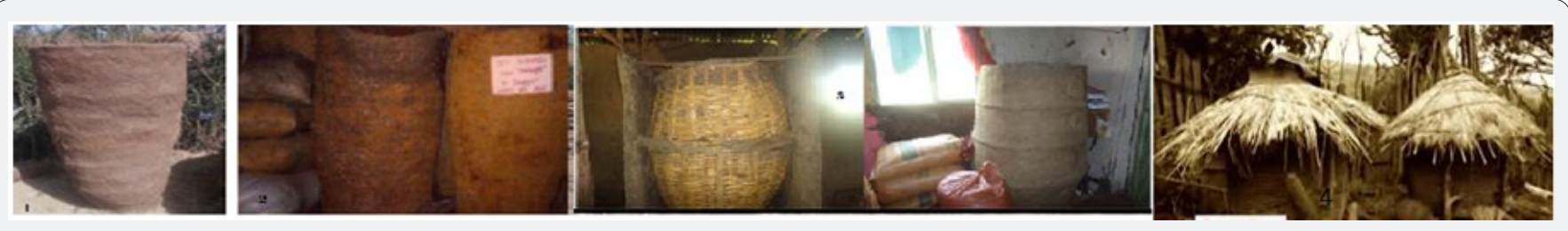

Figure 7: Tradtional teff storng in East showa $(2,3 \& 4)$ Tef stored inside Debgnt also called Doggo, which is placed inside the house in other teff growing area.

\section{Packaging}

The traditional ones are not preferred because of the odour that could affect the quality of the product. Modern packaging materials, especially plastic sacks, are much better since they prevent water from penetrating into the seeds. The size of packaging materials differs according to the amount of the seed to be stored or to be transported. For sale at the local market, small plastic sacks are preferred while for long distance transport, export sacks of bigger sizes which contain $100 \mathrm{~kg}$ tef are preferred. Packing is done within the family. Mostly women put the grains in the sacks and males close the sacks by hand sewing or tying with sisal or jute fibres.

\section{Farmer traditional knowledge on storage insect Pests}

Ninety eight percent of East Showa respondent answered that tef does not incur any loss as a result of serious damage by any storage insect pests under natural environmental conditions and traditional storage systems. However Trifolium castaneum (Herbst) was the only insect capable of multiplying itself effectively on undamaged whole tef and predominantly fed on the grain embryo [23]. T. destructor Uytt. Ephestia cautella (Wlk) showed some ability to produce surviving progeny on whole teff but is unlikely to become serious pests. Cryptolestes pusillus was able to infest teff in the presence of other insect species and also multiplied effectively on milled teff [23].

\section{Farmer awareness on Teff insect pest and disease}

Respondent in the study area were asked about insect pest destroy teff crops. Nighty five percent respondent answered those two pests with local language called Feanta and Adirk Til. However, 5 percent farmer responded that there are no serious pests associated with teff in the study area. Shoot fly (Atherigona spp.), Wello bush cricket (Decticoides brevipennis Ragge) and Red tef worm (Mentaxya ignicollis (Walker) are the most important insect pests of teff [24]. Tef shoot fly (Atherigona spp.) attacks tef throughout the crops active growing period. However, the seedling and panicle stage is the most critical [25] Larvae mine in to stems of the central shoots of tef causes "dead heart" symptoms because of internal feeding caused by shoot fly larvae [26]. It caused $42-58 \%$ damage to growing panicles in different varieties of tef, which resulted in an estimated loss of $378-522 \mathrm{~kg} / \mathrm{ha}$ [27]. But, Tef shoot fly (Atherigona spp.) is an economically important pest of tef in Wag-Lasta and in some other area cases can cause up to $100 \%$ yield loss. Different teff insect pest are recorded in different part of Ethiopia (Table 


\section{Agricultural Research \& Technology: Open Access Journal}

6). Tef rust (Uromyces eragrostidis Tracy) and head smudge (Helminthosporium miyakei NisijcacLi) have been reported as the most important diseases on tef and rust causes an average loss of $10-25 \%[8,28]$.

Table 6: Teff insect pest

\begin{tabular}{|c|c|c|}
\hline Scientifc Name & Common Name & Status \\
\hline Ailopus simulatrix (Walier) & Clay grasshoppertain & Uncertain \\
\hline Atherigona hyalinipennis (Emden) & Shootfly & Major \\
\hline Atherigona sp & Shootfly & cricket Major \\
\hline Delia arambourgi (Segny) & Barley fly & Minor \\
\hline Decticoides brevipennis (Ragge) & Wello bush cricket & Minor \\
\hline Diuraphis noxius (Mordv.) & Russian wheat aphid & Major \\
\hline Epilachna similis (Thumberg) & Tef epilachna & Uncertain \\
\hline Erlangerius niger (Weise) & Black tef beetle & Major \\
\hline Eysarcoris inconspicuus (Harrich-Schoeffer) & & Major \\
\hline Macrotermes subhyalinus (Rambur) & Mendi termite & Uncertain \\
\hline Mentaxya ignicollis (Walker) & Red tefworm & Minor \\
\hline Medicogryllus sp. & Crickets & --- \\
\hline Rhopalosiphum maidis (Fitch) & Maize aphid & Sporadic \\
\hline Rhopalosiphum padi (L.) & Oat aphid & Armyworm \\
\hline Spodoptera exempta (Walker) & Aroj & \\
\hline
\end{tabular}

\section{Type of teff weed and weed controlling method}

There are several weeds which reduce teff productivity. $96 \%$ of respondents list using vernacular naming about 13 different types of weed in their teff farm land (Table $7 \&$ Figure 8). According to weed invasiveness rate respondent prioritize Nechlebash, Faramsisa, Asendabo were dominant in all agro ecology. Hand weeding is the most widely used practice to control weeds in tef. $58.4 \%$ of farmer use different chemical spry for weed control however $41.6 \%$ pick traditionally by their hands where it is tiresome activity (Figure 9). All of the house hold will participate in weed picking activities. The teff yield losses due to weeds range between 23\% around the Debre Zeit area to 56\% in Shewa [29]. H 2-4-D herbicide is recommended at rate of 1 litter ha ${ }^{-1}$ to control broad-leaved weeds. However, teff farmers prefer twice hand weeding and in rare circumstances apply herbicide under the close supervision of extension workers. Agrochemical has adverse effect on soil microbiota, human health, and environment, soil health management is crucial for ensuring sustainable agricultural productions and maintenance of biodiversity. Respondents in the study area list different agro chemicals used for many years in their farm for weed control, pest control, anti-fungal chemicals, and yield improving chemicals for different vegetables, leguminous crop other cereal crop. Some of chemical input listed by respondent that percolate in to soil system are Galant, Pallas OD45, Malathion, 2.4 D amine, Road mill, Round up, sabozeb $80 \%$ WP. croplaunge. Urea, DAP, NPS (Table 7). Type of weed in teff farm land.

Table 7: Type of weed in teff farm land.

\begin{tabular}{|c|c|c|c|c|c|}
\hline Distric & Boset & Adama & Adaa & Lomme & Gimbichu \\
\hline Weed type & $\begin{array}{l}\text { Asendabo, } \\
\text { Fermsisa, } \\
\text { Kemun, } \\
\text { Wofankur, } \\
\text { Banda, } \\
\text { Nechlebash }\end{array}$ & $\begin{array}{l}\text { Banda, nechlebash, } \\
\text { Guri, Jere, Rafa, Guri, } \\
\text { Sinar, Quni(Gicha), } \\
\text { Migreseri, Nechlebash, } \\
\text { Gomenseri, Faramsisa }\end{array}$ & $\begin{array}{l}\text { Quni, Nechlebash Teto, } \\
\text { Migreseri, Qoretbe, } \\
\text { Fermsisa, Asendabo, } \\
\text { Grenchi, Senafich, Kitisa, } \\
\text { Abashifera, Ensilal }\end{array}$ & $\begin{array}{l}\text { Asendabo(Wobalo), Yewof gomen, } \\
\text { Sheket, Aluma, wofankure, Engicha, } \\
\text { Wofzerir, Sirana, Angago. Mech, } \\
\text { Quni, jere, Guri, Migreserie, Enboye, } \\
\text { Kumundo, Mormi, Menj, Abatebo, }\end{array}$ & $\begin{array}{l}\text { Ginchi, Asendabo, } \\
\text { Tult, Menji, Teto. } \\
\text { Faramsisa, Ensilal }\end{array}$ \\
\hline
\end{tabular}
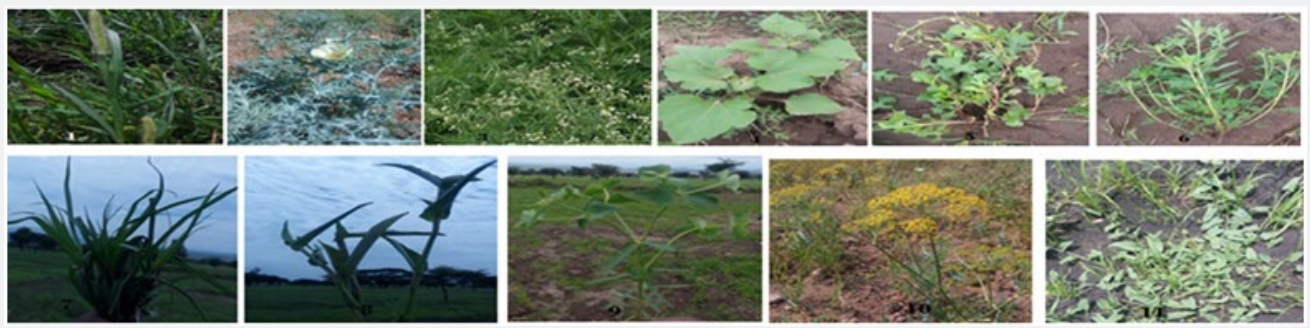

Figure 8: Severe weed in teff farm in the study area according to invasiveness rate in their vernacular name (1. Asendabo 2. Nechlebash 3. Faremsisa 4. Banda) and mild weed types in teff farm(5-11). 

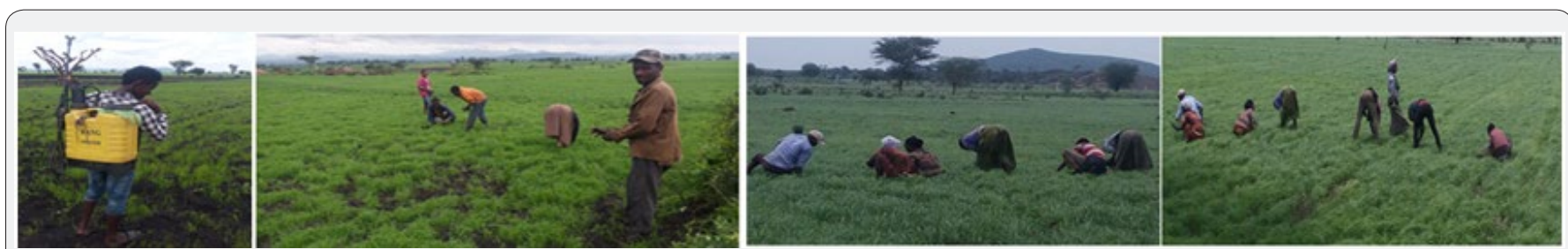

Figure 9: Herbicid and traditional weed picking practice in East showa.

Farmer's knowledge on inorganic fertilizer and pest side

Farmer asked about the use and utilization of inorganic fertilizer. $63.37 \%$ of respondent answered inorganic fertilizer increase teff productivity, Quality of teff grain increase (8.72\%), Market profitability increase (18.02\%), Straw quality increase (9.88\%) (Table 8 \& 9) however amount of inorganic fertilizer as well as method of application for different crop and utilization practice is so vary farmer to farmer and districts to districts. The type of fertilizer in the districts dominantly used Diammonium phosphate (DAP), Urea, NPS. 96\% of respondent also tell that teff productivity vary in different crop rotation and inorganic fertilizer application. The soil testing and consulting recommendations based on crop and yield goals are not that much done according to respondent. Before the introduction of mineral fertilizers in the nineteenth century, soil fertility was maintained mostly through recycling of organic materials and crop rotation that incorporated nitrogen-fixing leguminous crops [30], Fertilizers and pesticides are a necessary evil for industrial agriculture. Though, they continue to be critically important tools for global food security, their undesirable effects cannot be overlooked particularly when sustainable agriculture is the universal focus. Fertilizers and pesticides tend to have long persistence in the soil so they are bound to affect the soil biodiversity thereby disturbing soil health and soil functions like rhizodeposition, nutrient content of bulk and rhizospheric soil, soil organic carbon, $\mathrm{pH}$, moisture, activities of soil enzymes, rhizospheric microbial diversity and many others. The recovery rate of Phosphate fertilizer by plants is only about 10 to $30 \%$ $[7,31]$. The remaining 70 to $90 \%$ is accumulated in soil or in the form of immobile that is bound by $\mathrm{Al}$ or Fe in acid soils, or $\mathrm{Ca}$ and Mg in alkaline soils $[32,33]$. Frequent use of chemical fertilizers and narrow crop rotation can cause declining microbial biodiversity and soil fertility. Organic fertilizers provide nutrients and contribute to the quality of soil by improving the structure, chemistry, and biological activity level of the soil. They are known for the gradual release of nutrients, and they increase soil organic matter content [34].

Table 8: Respondent reason of using inorganic fertilizer and pesticide.

\begin{tabular}{|c|c|c|c|}
\hline & Pes & Respondent & Percentage \\
\hline $\begin{array}{c}\text { Is their impact in continuous use of Inorganic } \\
\text { fertilizer }\end{array}$ & No & 128 & 74.42 \\
\hline $\begin{array}{c}\text { Respondent reason on continuous use of } \\
\text { inorganic fertilizer and pesticide }\end{array}$ & $\begin{array}{c}\text { Farm land soil completely dependent on chemical } \\
\text { fertilizer and soil fertility decrease time to time }\end{array}$ & 74 & 25.58 \\
\hline & New diseases for human and their cattle are emerging & 34 & 19.02 \\
\hline & Stream, ground water existence and quality decrease & 23 & 13.37 \\
\hline & Grain and meat flavor decrease from previous time & 17 & 9.88 \\
\hline & Insect number and type decreased from previous time & 24 & 13.95 \\
\hline
\end{tabular}

Table 9: Method of application inorganic and pesticide.

\begin{tabular}{|c|c|c|c|}
\hline Variables & Response & $\begin{array}{l}\text { Respondent } \\
\text { Number }\end{array}$ & Percentage \\
\hline \multirow[t]{2}{*}{$\begin{array}{l}\text { Are there awareness on scientific method of inorganic } \\
\text { fertilizer application for all soil type and teff varity }\end{array}$} & yes & 87 & 50.58 \\
\hline & No & 85 & 49.42 \\
\hline \multirow[t]{4}{*}{$\begin{array}{l}\text { How they get information on method of inorganic } \\
\text { fertilizer application }\end{array}$} & Continuous agriculture office expert field training & 61 & 35.46 \\
\hline & Farmer training center(FTC) & 41 & 23.84 \\
\hline & Experienced farmer and elderly person & 24 & 13.95 \\
\hline & $\begin{array}{l}\text { By guessing from previous yield and through own } \\
\text { formulation }\end{array}$ & 46 & 26.74 \\
\hline $\begin{array}{l}\text { Productivity of teff vary in application of inorganic } \\
\text { fertilizer using different crop for rotation system }\end{array}$ & yes & 146 & 84.88 \\
\hline
\end{tabular}




\section{Agricultural Research \& Technology: Open Access Journal}

\begin{tabular}{|c|c|c|c|}
\hline & No & 26 & 15.11 \\
\hline $\begin{array}{c}\text { Is there any soil test to apply inorganic fertilizer from } \\
\text { each farm land and crop Varity }\end{array}$ & yes & 32 & 18.6 \\
\hline $\begin{array}{l}\text { Is there awareness on protective equipment proper } \\
\text { usage during pesticides use and inorganic fertilizer }\end{array}$ & No & 142 & 82.55 \\
\hline & Yes & 99 & 57.55 \\
\hline
\end{tabular}

\section{Traditional agro forestry system}

Agroforestry is a traditional ways introduced a dynamic, ecological based, natural resource management system through integration of trees on farms and agricultural landscapes that diversifies and sustains production for the purpose of increasing social, economic, and environmental benefits for land users at all levels [35]. The role of woody perennials in agroforestry systems can be both productive (producing food, fodder, fuel, fence, wood, etc.) and protective (soil conservation, shade during the harsh weather period, wind breaks and shelterbelts, etc. Depending on the nature and type of components involved, agro forestry system can be classified as agri silvi cultural (tree + crops), silvo pastural (tree + pasture and /or livestock) and agrosilvo pastural [36]. Recent data has shown that globally $46 \%$ of agricultural land has more than $10 \%$ tree cover [37], while $17 \%$ of farming land has more than $30 \%$ tree cover. In East shewa teff farming practice used traditional agroforestry system consists of different trees species in their farm land. $86.7 \%$ respondent of the study area listed different tree species in their local name in different land use type, Homestead, Boundary Mixed with crops, Grazing land,
Hedge row planting. Most of the farm land area dominated by Gerbi./Acacia albidia/A. abyssinica), Tedecha (Acacia tortilis), wacho (Table 10).

This study supported by most abundant species in homesteads was Acacia tortilis followed by Jatropha curcas, Croton macrostachyus and Azadirachta indica. While, Schinus molle followed by Jatropha curcas, Ricinus communis and Acacia tortilis were most abundant species in boundary planting. On farm plots Acacia tortilis followed by Balanites aegyptiaca, Acacia senegal, and Croton macrostachyus were most abundant species. Whereas, Balanites aegyptiaca, Eucalyptus camaldulensis and Cajanus cajan were most abundant species in grazing land, small scale woodlot and hedge row plantings respectively The remaining species exist having different abundance among various land practices [38]. Of all the species identified $26 \%$ belonged to the Fabaceae family, $7.8 \%$ to Capparidaceae and 7.7 to Euphorbiaceae, and these were the three dominant woody plant families in the landscape. Table 10 summarizes the list of tree in the study area with their velanaculr name.

Table10: Tree species in the study area.

\begin{tabular}{|c|c|c|}
\hline Districts & kebele & Tree types \\
\hline Bost & Gere, Digelo,Teri-Beriti & $\begin{array}{l}\text { Wangeyo(Acacia oerfota), Tedecha(Acacia tortilis),Wacho, Jemo,Gerbi. } \\
\text { Acacia albidia/A.abyssinica) }\end{array}$ \\
\hline Adma & $\begin{array}{c}\text { Adama distirics(Dabi soleke,Didibesana wachulafa, } \\
\text { GurjaFurda }\end{array}$ & $\begin{array}{l}\text { Tedecha((Acacia tortilis),Gerbi, Acacia albidia/A.abyssinica), Qurqura } \\
\text {,Bedeno }\end{array}$ \\
\hline Adaa & Adaa Districs (Malimo,chelba,Dire,Hidi, Mintlae & Gerbi,wacho,Dodeti,Lafto,Bokonisa(Bisna),Agam, Wanza. \\
\hline Lomme & $\begin{array}{l}\text { Tulurea bermrji,Tiltigerbi, Dingugi, Akabora,Ajersa } \\
\text { joro,Bika }\end{array}$ & $\begin{array}{l}\text { Wacho,Dedeho,Gerbi,Bisana,wotae, Tedecha, wanza,Derae,Lafto,Bedeno } \\
\text { keselae }\end{array}$ \\
\hline Gimbichu & Habri mitae, Adadi Guli kebeli & No tree with in farm except eucalyptuses around house near to farm land. \\
\hline
\end{tabular}

\section{Utilization of teff}

Farmers in East showa Zone used teff crope for different purposes. $96 \%$ of respondent produced flour from all teff variety for injera preparation (Figure 10). Teff grain is ground into flour and fermented dough baked to make injera. It is spongy, sourdough flatbread or a soft, porous, thin pancake traditionally consumed with wot, a sauce made of meat or ground pulses like Lentil (Lens culinaris), Faba bean (Vicia faba), Field pea (Pisum sativum), and Chickpea (Cicer arietinum). The traditional way of consuming teff-injera with wot provides a well-balanced diet because of the high nutritional composition of the whole grain [17]. Teff in Ethiopia is the preferred grain for making injera, primarily for its better sensory attributes (for example, taste, color, smell) $[39,40]$. The majority of farmers' used Kuncho,
Qoreta, Boset and Magna teff variety for home consumption and market sale. In the study area teff flour is also used for making Chechbisa, porridge, kitta (unleavened bread), and atmit or muk (gruel) and beverage ingredient. Various studies showed that in its injera making and keeping quality features, teff grain appeared superior among other cereal grains because of its high resistance to staling $[39,40]$. In Ethiopia, the grain is also used to make traditional local alcoholic beverages such as opaque beer called tella, a sprit called katikala/arake, and shamit at household level [41]. The teff grain, owing to its high mineral content, has started to be used in mixtures with soybean, chickpea, and other grains in the baby food industry [17]. An additional advantage is that teff is almost always grown and stored under organic conditions. Several recipes that fit Western tastes have 
been developed from teff flour particularly in the United States, where it has found niches in the health food market and as a gourmet food. Teff flour is used as a thickening agent in a range of products, including soups, stews, gravies, and puddings and, at least according to one promotional pamphlet, "its mild, slightly molasses-like sweetness makes tef easy to include in porridge, pancakes, muffins and biscuits, cookies, cakes, stir fry dishes, casseroles, soups, stews, and puddings [17].
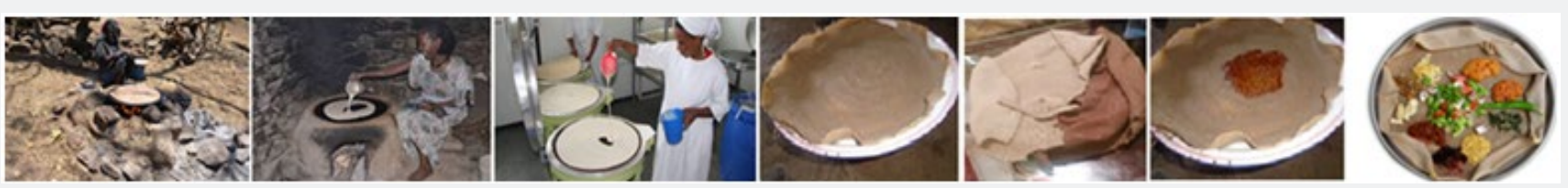

Figure 10: Injera baking and people usual dish.

\section{Farmer's knowledge on crop rotation and teff farming practice}

Farmers in East showa Zone were asked awareness about the role of crop rotation and strip cropping for teff farming. $96 \%$ respondents do have awareness about crop rotation useful in treating soil fertility and increasing teff yield and productivity per hectar. Ten different leguminous crop and cereal crops were widely used for crop rotation and strip cropping in the study area. These are Lentile (Lens culinaris), Vetch (Lathyrus sativus), Chickpea (Cicer arietinum), Wheat (Triticum aestivum L.), Onion (Allium cepa), Common bean (Phaseolus vulgaris) Fenugreek (Abish) (Trigonella foenum-graecum), Bean (Faba vicae), Pea, Maize (Zea maize). 95\% of respondent answered that Common bean(Phaseolus vulgaris) Chickpea (Cicer arietinum, Lentile (Lens culinaris, Vetch (Lathyrus sativus and Onion (Allium cepa), are top for crop rotation in East showa. 92.3\% respondent answered that Teff productivity differed in the type of crop used for rotation, in average $3000 \mathrm{~kg} / \mathrm{hectar}, 2625 \mathrm{Kg} / \mathrm{h}$ ektar, $2230 \mathrm{Kg} /$ hektar, $1700-2000 \mathrm{Kg} /$ hektar is obtained from crop rotated by Onion, Common bean, Chickpea and Lentil respectively (Figure 11 \& 12). Respondent reason out that onion became high due to excess inorganic fertilizer used during onion farming for bulb formation in turn phosphate left in the soil help to teff productivity. They also mentioned that chick pea and lentil root and leaf when decomposed very important to improve soil fertility and teff productivity. Most of the Ethiopian farmers use traditional varieties of Teff which is known to have a very low yield, around $910 \mathrm{~kg}$ per hectare. Modern varieties are also used in many regions such as Gojjam and Shewa but in very small areas. The yield of the modern varieties is estimated to be $1700-2200 \mathrm{~kg}$ per hectare on farmers' fields and $2200-2800 \mathrm{~kg}$ per hectare on research managed large farms [42]. Historically, since the time of the Romans and among indigenous cultures, planting legumes alongside a cereal crop, especially maize, has been a common practice for centuries $[43,44]$. Crop rotation presents several advantage compared to monoculture that can help increase soil organic matter, reduces the toxicity of several substances in the soil, by alternating root systems with different characteristics(tap, fascicular) and depths, improve soil porosity and structure, reduce soil erosion and runoff, recycle nutrients, improve soil physical properties, and also strategy in managing insect pest, disease, and weeds, reduced greenhouse gas emissions, reduced water pollution, increased ability to store carbon, decrease soil $\mathrm{pH}$, reduce soil compaction, diversify Plant growth promoting microorganisms and mitigate disease problems $[45,46]$.

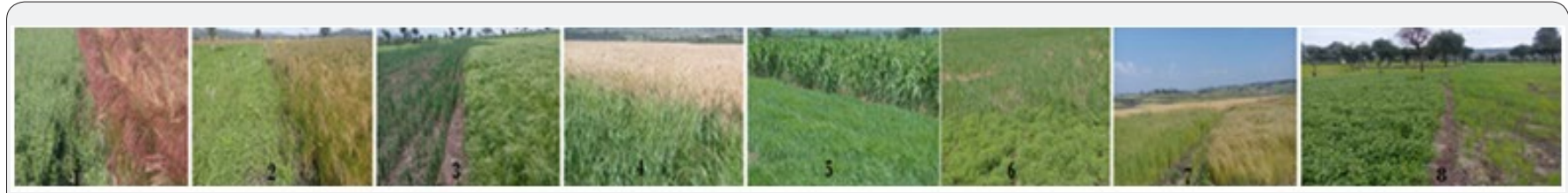

Figure 11: Pattern of strip cropping and crop rotation system 1. Teff with Chickpea 2. Teff with vetch 3. Teff with onion 4. Teff with wheat 5. Teff with maize 6. Teff with lentil 7. Two Teff varities . 8. Teff ith common bean.

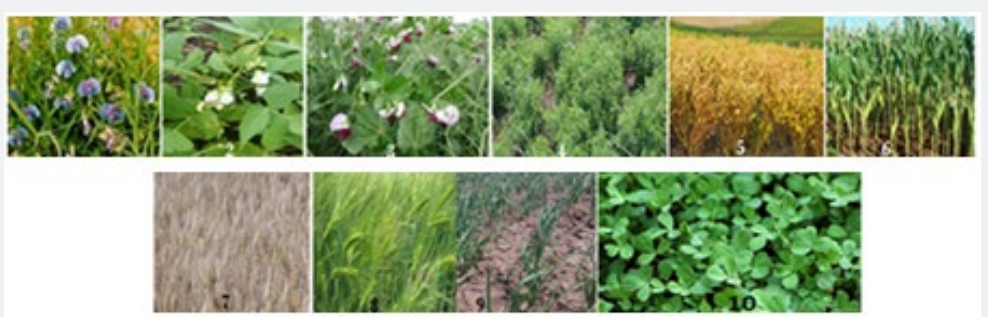

Figure 12: Farmers frequently used crops for rotation with teff farmland 1. Vetch (Lathyrus sativus 2. Common bean (Phaseolus vulgaris) 3. Pea (Pistum stvium) 4. Lentil (Lens culinaris) 5. Chickpea (Cicer arietinum) 6. Maize (Zeamays) 7. Wheat 8.Barley ( Hordeum vulgare) 9 Onion. 10. Fenugreek (Trigonella foenum-graecum). 


\section{Farmers knowledge on the role of soil microorganisms for soil fertility in teff farm}

Respondent in east Showa were asked about the role of microorganisms for soil fertility. $91.86 \%$ do not have awareness about the useful aspects of microorganisms for soil fertility and plant growth activities, however traditionally they used different techniques to improve soil fertility and increasing teff yield, $80 \%$ of respondent tell to renew and increase soil fertility by, thinning and repeated ploughing for three to five times, $86.7 \%$ respondent also used agri silvi cultural land use type. 94\% respondent used different chemical fertilizer and agrochemical for teff productivity, $96 \%$ of respondent used crop rotation using legume and cereal crop for soil fertility improvement and teff yield productivity. Soil represents the box of microbial diversity and favorable habitat for a variety of microorganisms. Soil carries $10^{8}-10^{9} \mathrm{Number} /$ gram of soil, biomass $40-500 \mathrm{~g} / \mathrm{m}^{2}$ of bacteria, $10^{5}-10^{6} \mathrm{Number} / \mathrm{g}$ of soil and $100-1500$ Biomass $(\mathrm{g} /$ $\mathrm{m}^{2}$ ) of Fungi, $10^{7}-10^{8}$ Number/g of Soil, 40-500 Biomass (g/ $\left.\mathrm{m}^{2}\right)$ Actinomycetes, $10^{4}-10^{5} \mathrm{Number} / \mathrm{g}$ of Soil, $1-50$ Biomass $\left(\mathrm{g} / \mathrm{m}^{2}\right)$ of algae, $10^{3}-10^{4}$ Number/g of Soil of Protozoa 102-103 Number/g of soil of Nematodes. However, on the basis of advanced analytical tools shown one million prokaryotic genomes per gram of soil [47]. The agriculturally beneficial microorganisms are plant growth promoting N-fixing cyanobacteria, rhizobacteria, mycorrhiza, plant disease suppressive beneficial bacteria, stress tolerance entophytes and bio-degrading microbes. Soil microbes transform mineral nutrients in soil like phosphate, zinc into plant available forms and provide other nutrients like nitrogen through symbiotic and non-symbiotic fixation processes [48]. Legumes are agronomically and ecologically important symbionts that lead to the development of new plant organ (legume nodule) in response to nitrogen fixing bacteria [49]. Rhizobia bacterium, ensures nitrogen is available to agricultural and garden crops with its symbiotic relationship with the legume [44]. The rhizosphere provides a specialized niche where microbes live and influence crop health and yield and is the zone of the symbiotic relationship between the legume and the microbe. Plant growth promoting rhizobacteria (PGPR) are a heterogeneous group of bacteria that can be found in the rhizosphere, at root surfaces and in association with roots, which can improve the extent or quality of plant growth directly and/or indirectly. In last few decades a large array of bacteria including species of Pseudomonas, Azospirillum, Azotobacter, Klebsiella, Enterobacter, Alcaligenes, Arthrobacter, Burkholderia, Bacillus, Rhizobium and Serratia have reported to enhance plant growth [50]. Rhizspher zone is rich in nutrients when compared with the bulk soil due to the accumulation of a variety of plant exudates, such as amino acids and sugars, providing a rich source of energy and nutrients for microorganisms [51]. The indirect promotion of plant growth occurs

i. The ability to produce or change the concentration of plant growth regulators like indoleacetic acid, gibberellic acid, cytokinins and ethylene [48,52],

ii. A symbiotic Nitrogen fixation [53],

iii. Antagonism against phytopathogenic microorganisms by production of hydrogen cyanide, siderophores production for scavenging iron minerals [54], antibiotics production to control pathogenic fungi [55] and cyanide production for weed and pathogenic fungi control [11].

iv. Solubilization of mineral phosphates and other nutrients [56,57].

Plant growth promoting microbs (PGP) may promote plant growth indirectly by affecting symbiotic N2 fixation, nodulation or nodule occupancy [58]. The most efficient Phosphate solubilizing microbs (PSM) belong to genera Bacillus, Rhizobium and Pseudomonas, Aspergillus and Penicillium. Legumes show a high positive response to Phosphate supplementation [59]. Phosphate solubilizing bacterial strains was isolated from lentil rhizosphere in Ethiopia which has multiple plant growth and promotion effect [60]. Farmers in the study area using different leguminous and cereal crop for rotation and intercropping to increase soil fertility and teff productivity, these concluded that they indirectly rehabilitate very important plant growth promoting microbial community into the soil having role for nitrogen fixation, phosphate solubilization, phyto hormone production, antibiotic production, pathogen inhibitors, sidrophore production (Table 11).

Table 11: Some Rhizosheric microbial diversity associated with leguminous and cereal crop.

\begin{tabular}{|c|c|c|}
\hline Fenugreek & S. meliloti, Exiguobacterium sp, & Geetha et al.,2012 \\
\hline & Enterobacter cloacae, Pantoea dispersa and Enterobacter ludwigii & Pranab Roy et al.,2016[86] \\
\hline \multirow[t]{2}{*}{ Chick pea } & $\begin{array}{l}\text { Rhizobium leguminosarum, Mesorhizobium ciceri, Mesorhizobium } \\
\text { mediterraneum, Pseudomonas aeruginosa, } \text { M. tianshanense }\end{array}$ & $\begin{array}{c}\text { Zeenat et al.2017, [100]Rivas etal., 2006[88], } \\
\text { Anjair et al., 2003[67] }\end{array}$ \\
\hline & Rhizobium phaseoli, Bradyrhizobium japonicum & Datta et al., 2015[49] \\
\hline \multirow[t]{4}{*}{ Bean } & Burkholderia cepacia, Pseudomonas fluorescens, klebsella spp. & Fekadu,2016 \\
\hline & $\begin{array}{c}\text { Pseudomonas cedrina ,Rahnella aquatilis, Rhizobium nepotum, Rhizobium } \\
\text { tibeticum) }\end{array}$ & Abderrazak Rfaki eta al., 2015[63] \\
\hline & $\begin{array}{c}\text { Sinorhizobiummeliloti and Sinorhizobium fredii , R. leguminosarum, } R \text {. } \\
\text { giardinii }\end{array}$ & Sadowsky et al 1998[91] \\
\hline & R. tropici, Rhizobium etli & \\
\hline
\end{tabular}




\begin{tabular}{|c|c|c|}
\hline Lentil & $\begin{array}{c}\text { Acinetobacter, Agrobacterium, Bacillus, Burkholderia, Chryseomonas, } \\
\text { Enterobacter, Pseudomonas, Ralstonia and Sphingomonas. }\end{array}$ & Mulissa et al.2015[60] \\
\hline \multirow[t]{4}{*}{$\begin{array}{l}\text { Common } \\
\text { bean }\end{array}$} & $\begin{array}{l}\text { Rhizobium leguminosarum sv. phaseoli, Rhizobium phaseoli, Rhizobium } \\
\text { tropici, Rhizobium etli, Rhizobium leucaenae, Rhizobium giardinii sv. phaseoli, } \\
\text { Rhizobium. gallicum, Rhizobium lusitanum, Rhizobium pisi, Rhizobium freirei, } \\
\text { Rhizobium mesoamericanum, Rhizobium paranaense, Rhizobium giardinii sv. } \\
\text { giardinii, Rhizobium.miluonense and Rhizobium ecuadorense, Leucaena spp., } \\
\text { Macroptilium gibbosifolium, Crotalaria pumila and Dalea leporina }\end{array}$ & $\begin{array}{c}\text { (Ribeiro et al. 2015[89]) (Jordan, 1984[78]), } \\
\text { (Martínez-Romero et al., 1991[84]), (Segovia } \\
\text { et al., 1993[94]), Mart|ènez et al., 1985[44]., } \\
\text { Hungria.,1997 }\end{array}$ \\
\hline & $\begin{array}{l}\text { Bacillus, Arthrobacter, Brevibacterium, Lycinibacillus, Enterobacter, } \\
\text { Acetinobacter, Pseudomonas, Klebsiella, Devosia, and Chryseobacterium. }\end{array}$ & Amarger et al., 1997,[65] \\
\hline & $\begin{array}{l}\text { Agromyces, , Brevibacillus, Delftia, Dietzia, Enterobacter, Methylobacterium, } \\
\text { Microbacterium, Micrococcus, Paenibacillus, Pseudomonas, Rhodococcus, } \\
\text { Sphingobacterium and Stenotrophomonas Acinetobacter, Brevundimonas, } \\
\text { Frigoribacterium, Kocuria, Sphingomonas, Sporosarcina and Staphylococcus }\end{array}$ & $\begin{array}{l}\text { Azanza.,et al 2006[68], Berg et al., 2005[69], } \\
\text { Barzanti et al., 2007[71], Ulrich,et al.,2008[98], }\end{array}$ \\
\hline & $\begin{array}{l}\text { Enterobacterhormaechei, Pseudomonas koreensis, Providenciarettgeri, } \\
\text { Pseudomonas koreensis, Enterobacter cloacae, Klebsiellapneumoniae, } \\
\text { Enterobacterhormaechei, Enterobacterasburiae, Acinetobactercalcoaceticu }\end{array}$ & ( Wekesa C., et al.,2017[4]) \\
\hline \multirow[t]{7}{*}{ Wheat } & $\begin{array}{l}\text { Stenotrophomonas rhizophila, Acetobactor pasteurianus. Bacillus sp, } \\
\text { Stenotrophomonas spS. maltophilia, P. fluorescens and B. fusiformis }\end{array}$ & $\begin{array}{l}\text { Afshan.,et al., 2015[66], deFreitas et al., } \\
\text { 1997[56]; Suckstorff and Berg, 2003[92]; Vessey, } \\
\text { 2003[99]). }\end{array}$ \\
\hline & $\begin{array}{l}\text { (Azospirillum, Azoarcus, Azotobacter, Bacillus polymyxa, Burkholderia, } \\
\text { Gluconoacetobacter or Herbaspirillum). Azotobacter chroococcum, Bacillus } \\
\text { circulans, Cladosporium herbarum }\end{array}$ & Boddey et al. 1986[70]), Kumar and Narula, 1999 \\
\hline & & (Singh and Kapoor, 1999[93]) \\
\hline & Burkholderia cepacia, Enterobacter agglomerans, Ochrobactrum anthropi, & Morales et al. (1996),[83] \\
\hline & Ochrobactrum tritici, Pseudomonas aeruginosa, Salmonella typhimurium, & Germida and Siciliano (2001)[77] \\
\hline & Staphylococcus aureus, Stenotrophomonas maltophilia, Streptococcus & \\
\hline & pyogenes & \\
\hline \multirow[t]{5}{*}{ Maize } & S. maltophilia, P. fluorescens and B. fusiformis & $\begin{array}{l}\text { deFreitas et al., 1997[56]; Suckstorff and Berg, } \\
\text { 2003[92]; Vessey, 2003)[99]. }\end{array}$ \\
\hline & $\begin{array}{c}\text { Bacillus polymyxa, Bacillus pantothenticus, Bacillus anthracis, Bacillus } \\
\text { thuringiensis, and Bacillus circulans, Pseudomonas. cichorii, Pseudomonas } \\
\text { putida, Pseudomonas syringae and Serratia marcescens }\end{array}$ & Nadège et al.,2015 \\
\hline & Achromobacter piechaudii & Mayak et al. (2004a)[14] \\
\hline & Azospirillum, Bradyrhizobium, and Ideonella & Roesch et al. (2007)[90] \\
\hline & $\begin{array}{l}\text { Burkholderia cepacia, Klebsiella pneumoniae, Serratia liquefaciens, } \\
\text { Sphingomonas paucimobilis, Stenotrophomonas maltophilia }\end{array}$ & $\begin{array}{l}\text { Lambert et al. (1987)[80] Dalmastri et al. (1999) } \\
\text { [73] Chelius and Triplett 2000)[72] }\end{array}$ \\
\hline Vetch & Proteobacteria, Bacteroidetes and Cyanobacteria. R. leguminosarum & Y.J. Qiao,et al 2012[96] \\
\hline Onion & $\begin{array}{c}\text { Azotobacter, Azospirillum, Pseudomonas, Bacillus, Actinobacterium citricoccus } \\
\text { zhacaiensis }\end{array}$ & Mahmoud,2011[85] \\
\hline Teff Varity & $\begin{array}{c}\text { Cryptococcus albidus var albidus, Cryptococcus luteollus, Rhodotrula } \\
\text { aurantiacaB, Cryptococcus albidus var diffluens, Candida etchellsii, } \\
\text { Cryptococusterrus A, Cryptococcus albidus var aerius, Rhodotrula aurantiaca } \\
\text { A,Trichosporon beigelii B, Cryptococcus luteolus, Rhodotrula aurantiacaA, } \\
\text { Penicillium purpurogenum var. rubrisclerotium, Neosartorya fisheri var. } \\
\text { fischeri, Candida montana, Zygo ascus hellenicus }\end{array}$ & Birhanu et al.,(2016)[21] \\
\hline
\end{tabular}

\section{Soil type for teff farming in East showa}

Soils vary from locality to locality as different soil types are formed basically based on parent materials, climate, vegetation, altitude, latitude and interaction among these factors. 90\% Farmer in the study area listed 3 types soil used for teff production called in their local language. These are koticha, Gomborae, Charae (Figure 13). According to the zone statistics and information center and based on FAO's soil classification, about 9 major types of soils are found in the Zone and such groups are based on their origin as well as variations in the process of their formation. The major types of soils can be categorized into Andosols, Vertisols, Cambisols, Regosols, Luvisols, Phaeozems and Fluvisols forming the major soil group of high agricultural potential [61]. For instance Andosols (Mollic and Vitric Andosols) are light, loose, and porous, have high drain ability and absorb much water. They extend over larger portions of Adamitulu Jido Kombolcha, Boset, Dugda, Adama, Lomme and Bora districts of the zone, accounting for about $23.43 \%$ of the land area of the zone. Other groups such as Vertisols also found in the northern 
Lomme and are heavy, mostly dark colored clay soils containing more than $30 \%$ clay content. Such soils are fairly good, but limited agricultural potential. Phaeozems groups which are in most cases sodic having limited agricultural value are found in Dugda and Bora, and smaller portions of Ade'a, Adama and Liben Chukala districts of the zone [61]. Tef gives better grain yield and possesses higher nutrient contents, especially protein, when grown on Vertisols rather than on Andosols [17]. Most of the Ethiopian soils contain low nutrient content due to erosion and absence of nutrient recycling. In addition, most of the areas used for production of grains especially tef, wheat and barley fall under the low fertility soils [62-75].

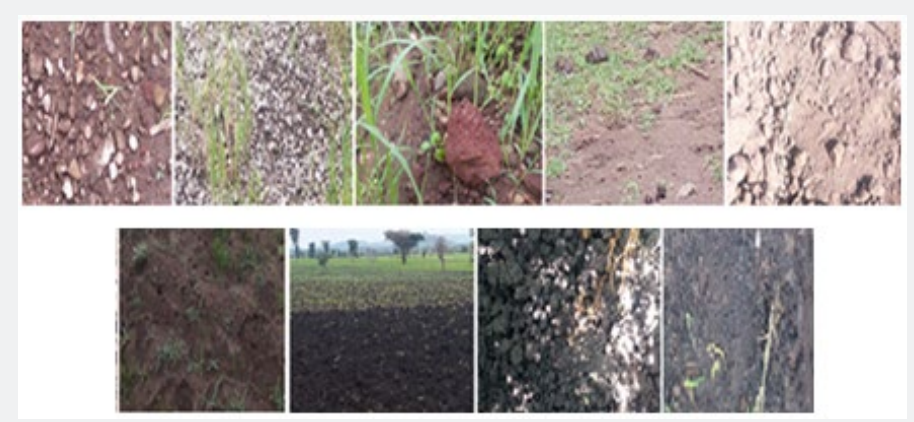

Figure 13: Physical feature of soil type in the study area.

\section{Conclusion}

Farmers used Vetch (Lathyrus sativus Common bean (Phaseolus vulgaris), Pea (Pistum stvium). Lentil (Lens culinaris), Chickpea (Cicerarietinum), Maize (Zeamays). Wheat (Triticum aestivum L.), Barley (Hordeum vulgare. Onion (Allium cepa), Fenugreek (Trigonella foenum-graecum) for crop rotation to increase soil fertility.

Frequent use of chemical fertilizers and narrow crop rotation can cause declining microbial biodiversity and soil fertility [7585].

The act of farmer using leguminous crop for crop rotation in teff yield and productivity is due to that indirectly enriching plant growth promoting microbes in the soil.

Farmers in East Showa Zone used teff varieties for different purposes, injera making, porrage, gruel, Chechebsa, Qita (unleavened bread, Alcoholic drink (Tella) Sprite (Areke).

There are 13 local and improved teff variety called by their local name are cultivated currently these are Magna, Sergegna, Bunign, kuncho, Qoreta, Bost, Package, Oromia, Shenkore, Cross37, Kora. Gemechis, Dagim.

Both gender that is male and female do have role in teff Farming practice and management. Farmers used traditional equipment for teff farming made from banboo, wood and iron. Indigenous knowledge is a store of experience and awareness of native society on technologies, practices and beliefs that forms the basis for production of different crops [85-90].

Indigenous knowledge on teff production and management system with their selection criteria has tremendous contribution for cultivar development; mechanized agriculture, improve threshing technology, improved management practices, develops teff genetic resources conservation strategies, as well as bio fertilizer development for present and future generation
Farmer education and training via an extension service is the most effective means of creating the awareness and understanding of right and responsible fertiliser use.

Traditional pile making in teff is very important to increase teff grian mass and injera gloss.

\section{Recommendation}

Soil scientist and microbiologist as well as researcher should study in depth the role microorganisms for soil fertility improvement during crop rotation with teff farming system to produce bio fertilizer based on farmer traditional Knowledge[91-94].

Agricultural policies, subsidies and research/extension which promote modern varieties and Farming technologies, at the expense of traditional local knowledge and biodiversity.

Before the addition of inorganic fertilizer in to the soil it is important to know plant growth promoting microbial community and soil mineral content in the farming soil.

The Agrochemical impact on soil biodiversity, health and environment must be studied in depth by researcher.

Compost and bio fertilizer development should be encouraged for teff productivity. Farmer traditional knowledge on farming practice in different crop should be documented. Teff threshing must be supported by new technology. Agronomist, crop breeder, soil scientist, microbiologist must work together in harmony for teff productivity and lodging problem [95-100].

\section{Acknowledgment}

The Author would like to thank and pleasure to acknowledge Dr Genene Tefera for his unreserved guidance and encouragement and support in providing and facilitating the nessaccery equipment. And extremely grateful to acknowledge regional ,zonal, district and Keble leader in the research area who helped 
us guiding the study area also my wife Beltu Mebrahtom here inert contribution during writ up and finally goes to Ethiopian biodiversity institute for financial support, Microbial directorate and its research team for their for technical and un reserved support

\section{References}

1. Tella RD (2007) Towards Promotion and Dissemination of Indigenous Knowledge. A Case of NIRD. The International Information and Library Review 39 pp. 185.

2. Teklu Y, Tefera H (2005) Genetic Improvement in Grain Yield Potential and Associated Agronomic Traits of Tef (Eragrostis Tef). Euphytica 141(3): 247-254.

3. Simoons FJ (1965) Some questions on the economic prehistory of Ethiopia. J Afr His 6(1): 1-13.

4. Wekesa CS, Muoma J, Ombori O, Maingi J, Okun D (2017) Genetic Characterization of Rhizosphere Bacteria that Inhabit Common Bean Nodules in Western Kenya Soils. Appli Micro 3: 128.

5. Costanza SH (1974) Literature and numerical taxonomy of tef (Eragrostis tef). MSc Thesis, Cornell University, Urbana, Illinois.

6. Collyns Dan (2013) Quinoa brings riches to the Andes.

7. Stevenson FJ (1986) Cycles of soil carbon, nitrogen, phosphorus,sulphur and micronutrients. Wiley, New York, USA, pp. 201.

8. Taddesse Ebba (1969) Teff (Eragrostis tef). The cultivation, usage and some of the known diseases and insect pests, Part-1. Debre Zeit Agricultural Experiment Station Bulletin No. 60. Alemaya University of Agriculture, Dire Dawa, Ethiopia.

9. Hungria M, Neves MCP (1987) Cultivar and Rhizobium strain effect on nitrogen fixation and transport in Phaseolus vulgaris L. Plant Soil 103(1): 111-121.

10. Central Statistical Authority (CSA) (2012/2013) Agriculture Sample Survey. Report on Area and Production for Major Crops. Statistical Bulletin No 532 CSA, Addis Ababa, Ethiopia.

11. Flaishman MA, Eyal ZA, Zilberstein A, Voisard C, Hass D (1996) Suppression of Septoria tritci blotch and leaf rust of wheat by recombinant cyanide producing strains of Pseudomonas putida. Molecular Plant-Microbe Interactions 9(7): 642-645.

12. Daniel WW (1999) Biostatistics: A Foundation for Analysis in the Health Sciences. ( $7^{\text {th }}$ edn), John Wiley \& Sons, New York, USA.

13. Berhane G, Paulos Z, Tafere K, Tamru S (2011) Food grain consumption and calorie intake patterns in Ethiopia.

14. Mayak S, Tirosh T, Glick BR (2004) Plant growth promoting bacteria that confer resistance to water stress in tomatoes and peppers. Plant Sci 166: 525-530.

15. Yared D, Tewodros M (2014) Exploring Indigenous Knowledge and Production Constraints of Taro (Colocasiaesculenta L. (SCHOTT)) Cultivars Grown at Dalbo Watershed, Wolaita Zoneof South Ethiopia. Greener J Plant Breeding and Crop Sci 2(3): 047-053.

16. Wundensh H (1999) In: Workshop on institutionalizing gender in agricultural technology generation and transfer processes. 25-27 October 1999. Addis Ababa Ethiopia. (Unpublished).

17. Seyfu Ketema (1997) Tef - Eragrostis tef (Zucc) Trotter. Promoting the conservation and use of underutilized and neglected crops, Biodiversity International publ p. 12.

18. Cufodontis G (1974) Enumeration plantarum aethiopiae spermatophyta. Jard Bot Brussels.
19. Tadesse Ebba (1975) Tef (Eragrostis tef) cultivars. Morphology and classification. Part II. Expt. Sta. Bul. 66. Addis Ababa University College Agriculture. Dire Dawa.

20. Daniel T, Teferi A, Tesfaye W (2016) Evaluation of improved varieties of teff in West Belessa, northwest Ethiopia Review of Plant Studies 3(1): $1-6$.

21. Birhanu Gizaw, Zerihun Tsegay, Genene Tefera, Endegena Aynalem, Misganaw Wassi (2016) Farmers Traditional Knowledge on Teff (Eragrostistef) Farming Practice and Crop Rotation in PGP Microbes Enhancement for Soil Fertility in West and East Gojam. Computational Biology and Bioinformatics 4(6): 45-54.

22. Kassier SB (2002) Comparative responses of fodder and grain teff (Eragrostis tef (Zucc.) Trotter) cultivars to spatial, temporal and nutritional management. Thesis (MSc Agric), University of Natal, Pietermaritzburg.

23. McFarlane JA, Dobie P (1972) Susceptibility of $t$ 'ef (Eragrostis abyssinica Schrad.) to infestation by some insect pests of stored grain. J Stored Prod Res (Great Britain) 8: 177-182.

24. Hein B (1989) Insect pests of cereals in Ethiopia identification and control methods. Crop Protection and Regulatory Department, Ministry of Agriculture, Addis Ababa, Ethiopia.

25. Bahyeh M, Biruk W, Gezahegne G, Belay E (2009) The significance of tef shoot flies on tef and their control in Western and South western Zones of Shoa, Central Ethiopia. Annual plant protection society of Ethiopia, Addis Ababa, Ethiopia.

26. Davidson A (1969) Effect of some systemic insecticides on an infestation of the barley fly, Delia arambourgi in Ethiopia. E Afr Agr Forestry J 34(4): 422-425.

27. Gudeta S (1997) Biology of the Tef Shootfly, Atherigona hyalinipennis Van Emden in Eastern Ethiopia. Int J Trop Insect Sci 17(3-4): 349-355.

28. Stewart, RJB, Dagnachew Yirgou (1967) Index of plant diseases in Ethiopia. Experiment Station Bulletin No. 30. Alemaya University of Agriculture Dire Dawa Ethiopia.

29. Rezene F, Zerihun T (2001) Weed research in tef. In: Hailu T, Getachew B, Mark S (Eds.), Narrowing the Rift. Debre Zeit, Ethiopia, pp. 191-200.

30. FAO (2003) Fertilizer and the future IFA / FAO Agriculture conference on Global Food Security and role of sustainability. Fertilization Rome, Italy, V1-2.

31. Holford ICR (1997) Soil phosphorus: its measurement, and its uptake by plants. Austr J Soil Res 35(2): 227-239.

32. Prochnow LI, Fernando J, Quispe S, Artur E, Francisco B, Braga G, et al. (2006) Effectiveness of phosphate fertilizers of different water solubility's in relation to soil phosphorus adsorption. Soil and Plant Nutrition 63(4).

33. Yang M, Ding G, Shi L, Feng J, Xu F, Meng J (2010) Quantitative trait loci for root morphology in response to low phosphorus stress in Brassica napus. Theor Appl Genet 121(1):181-193.

34. Sarkar S, SR Singh, RP Singh (2003) The Effect of Organic and Inorganic Fertilizer on Soil Physical Condition and the Productivity of Rice-Lentil Cropping Sequence in India. Journal of Agricultural Science 140 (4): 419-425.

35. World Agroforestry Center (WAC) (2003) Agroforestry. Arbrus et Agricultures Multietagees D Afrique. CTA, Wageningan, the Netherlands pp. 280.

36. Gholz H (1987) Agroforestry Reality, Possibilities and Potentials. Martingus, Nijhoff Publishers in Cooperation with ICRAF.

37.Zomer RJ, Trabucco A, Coe R, Place F, van Noordwijk M, et al. (2014) Trees on farms: an update and re analysis of agroforestry's global 
extent and socio-ecological characteristics. Working Paper 179. Bogor, Indonesia: World Agroforestry Centre (ICRAF) Southeast Asia Regional Program.

38. Zerihun Woldu, Masresha Fetene, Asferachew Abate (1999) Vegetation under different Tree Species in Acacia Woodland in the Rift Valley of Ethiopia Sinet, Ethiop J Sci 22(2) 237-254.

39. Zegeye A (1997) Acceptability of injera with stewed chicken. Food Qual Prefer 8: 293-295.

40. Yetneberk S, Kock HL, Rooney LW, Taylor JRN (2004) Effects of sorghum cultivar on injera quality. Cereal Chem 81: 314-321.

41. Gupta PK, Tsuchiya T (1991) Chromosome engineering 111 plants: genetics, breeding, evolution. Elscvier, Amsterdam, Netherlands.

42. Engdawork T (2009) Understanding Teff: A Review of Supply and Marketing Issues. ECA Ethiopia Commodity Exchange Authority.

43. Formiga A (2011) Celebrate the three sisters: Corn, beans and squash.

44. Martinez E, Pardo MA, Palacious R, Cevallos MA (1985) Reiteration of nitrogen fixation gene sequences and specificity of Rhizobium in nodulation and nitrogen fixation in Phaseolus vulgaris. Journal of General Microbiology 131: 1779-1786.

45. Cook RL, Ellis BG (1987) Soil Management: A worldview of conservation and production. John Wiley \& Sons. New York, Singapore, pp. 152-170.

46. USDA (1998) Soil Quality - Agronomy Technical Note, access on 30 August 2011.

47. Gans J, Wolinsky M (2005) Computational improvements reveal great bacterial diversity and high metal toxicity in soil. Science 309(5739): 1387-1390.

48. Glick BR (1995) The enhancement of plant growth promotion by free living bacterial. Can J Microbiol 41(2): 109-117.

49. Datta A, Singh RK, Kumar S (2015) Isolation, characterization and growth of Rhizobium strains under optimum conditions for effective biofertilizer production. Int J Pharm Sci Rev Res 32(1): 199-208.

50. Kloepper JW, Lifshitz R, Zablotowicz RM (1989) Free-living bacterial inoculum for enhancing crop productivity. Trends in Biotechnology 7 (Suppl 2): 39-43.

51. Gray EJ, Smith DL (2005) Intracellular and extracellular PGPR: Commonalities and distinctions in the plant-bacterium signaling processes. Soil Biol Biochem 37(3): 395-412.

52. Arshad, M, Frankenberger JWT (1993) Microbial production of plant growth regulators. In: Blaine F, Metting JR. (Eds.), Soil Microbial Ecology. Marcel and Dekker, Inc., New York, USA, pp. 307- 347.

53. Boddey RM, Dobereiner J (1995) Nitrogen fixation associated with grasses and cereals: recent progress and perspectives forthe future. Plant and Soil 42(Issue 1-3): 1-3.

54. Scher FM, Baker R (1982) Effect of Pseudomonas putida and a synthetic iron chelator on induction of soil suppressiveness to Fusarium wilt pathogens. Journal of Phytopathology 72(12): 1567-1573.

55. Shanahan P, Osullvan DJ, Simpson P, Glennon JD, Ogara F (1992) Isolation and characterization of an antibiotic-like compound from a fluorescent pseudomonad and investigation of physiological parameters influencing its production. Applied and Environmental Microbiology 58(1): 353-358.

56. DeFreitas JR, Banerjee MR, Germida JJ (1997) Phosphate solubilizing Rhizobacteria enhance the growth and yield but not phosphorus uptake of Canola (Brassica napus L.). Biol Fert Soils 24(4): 358-364.

57. GaurAC (1990) Physiological functions of phosphate solubilizing micro-organisms. Omega Scientific Publishers, New Delhi, p. 16-72.
58. Fuhrmann JJ, Wollum AG (1989) Nodulation competition among Bradyrhizobium japonicum strains as influenced by rhizosphere bacteria and iron availability. Biology and Fertility of Soils 7(Suppl 2): 108-112.

59. Gyaneshwar P, Kumar GN, Parekh LJ, Poole PS (2002) Role of soil microorganisms in living P nutrition of plants. Plant and Soil245 (1): 83-93.

60. Mulissa J, Midekssa Carolin, Löscher R, Ruth A Schmitz, Fassil Assefa (2015) Characterization of phosphate solubilizing rhizobacteria isolated from lentil growing areas of Ethiopia. African Journal of Microbiology Research 9(25): 1637-1648.

61. East Shewa Zone Finance and Economic Development Office (2011) (unpublished). Physical Geography of East Shewa Zone, Zonal Statistics and Information Center, Adama.

62. Hailu T, Seyfu K (2001) Production and importance of tef (Eragrostis tef $(Z u c c)$ Trotter) in Ethiopian Agriculture. In: Tefera H, Belay G (Eds.), Tef research and development proceeding of the "International work shop on tef genetics and improvement. Debre Zeit, Ethiopia.

63. Abderrazak R, Laila N, Jamal I (2015) Isolation and Characterization of Phosphate Solubilizing Bacteria from the Rhizosphere of Faba Bean (Vicia faba L.) in Meknes Region, Morocco. British Microbiology Research Journal 6(5): 223-234.

64. Adugna H, Kemal (1986) A review of weed control research activities on tef in Ethiopia. In: Tsedeke A (Eds.), A review of crop protection research in Ethiopia. Proceedings of the First Ethiopian Crop Protection Symposium. Addis Ababa, Ethiopia, pp. 55-77.

65. Amarger N, Macheret V, Laguerre G (1997) Rhizobium gallicum sp. nov. and Rhizobium giardinii sp. nov., from Phaseolus vulgaris nodules. Int J Syst Bacteriol 47(4): 996-1006.

66. Afshan Majeed, Kaleem Abbasi M, Sohail Hameed, Asma Imran, Nasir Rahim (2015) Isolation and characterization of plant growthpromoting rhizobacteria from wheat rhizosphere and their effect on plant growth promotion. Front Microbiol 6: 198.

67. Anjair V, Cornelis P, Koedom N (2003) Effect of genotype and root colonization in biological control of Fusarium wilts in pigeon pea and chickpea by Pseudomonas aeruginosa PNA1. Can J Microbiol 49(2): 8591.

68. Azanza MP, Azanza V, Vargas VM, Hedreya CT (2006) Bacterial endosynbionts of Pyrodinium bahamense Var compressum. Microbial Ecol 52(4): 756-764.

69. Berg G, Krechel A, Ditz M, Faupel A, Ulrich A, et al. (2005) Comparison of endophytic and ectophyticpotato-associated bacterial communities and their antagonistic activity against plant pathogenic fungi. FEMS Microb Ecol 51: 215-229.

70. Boddey M, Baldani VLD, Baldani JI, Dobereiner J (1986) Effect of inoculation of Azospirillum spp. on nitrogen accumulation by field grown wheat plant soil. Plant and Soil 95(1): 109-121.

71. Barzanti R, Ozino F, Bazzicalupo M, Gabbrielli R, Galardi F, et al. (2007) Isolation andcharacterization of endophytic bacteria from the nickel hyperaccumulator plant Alyssum bertolonii. Microb Ecol 53(2): 306316.

72. Chelius MK, Triplett EW (2000) Immunolocalization of dinitrogenase reductase produced by Klebsiella pneumonia in association with Zea mays L. Appl Environ Microbiol 66(2): 783-787.

73. Dalmastri C, Chiarini L, Cantale C, Bevivino A, Tabacchioni S (1999) Soil type and maize cultivar affect the genetic diversity of maize rootassociated Burkholderia cepacia populations. Microb Ecol 38(3): 273284.

74. ENI (1980) Ethiopian traditional recipes. Ethiopian Nutrition Institute, Addis Ababa, Ethiopia. 
75. Alemu F (2016) Isolation of Pseudomonas flurescens from Rhizosphere of Faba Bean and Screen Their Hydrogen Cyanide Production Under in vitro stduy, Ethiopia. American Journal of Life Sciences 4(2): 13-19.

76. Rajendran G, Patel MH, Joshi SJ (2012) Isolation and Characterization of Nodule-Associated Exiguobacterium sp. from the Root Nodules of Fenugreek (Trigonella foenum-graecum) and Their Possible Role in Plant Growth Promotion. Int J Microbiol 2012: 693982.

77. Germida JJ, Siciliano SD (2001) Taxonomic diversity of bacteria associated with the roots of modern, recent and ancient wheat cultivars. Biol Fertil Soils 33(5): 410-415.

78. Jordan DC (1984) Family III. Rhizobiaceae Conn 1938. In: Krieg NR, Holt JG (Eds.), Bergey's Manual of Systematic Bacteriology. Williams \& Wilkins, Baltimore, pp. 234-235.

79. Klug MJ, Tiedje JM (1993) Response of microbial communities to changing environmental condi-tions: chemical and physiological approaches. In: Guerrero R, Pedros-Alio C (Eds.), Trends in microbial ecology. Spanish Society for Microbiology, Spain, pp. 371-378.

80. Lambert B, Frederik L, Van Rooyen L, Gossele F, Papon Y, et al. (1987) Rhizobacteria of maize and their antifungal activities. Appl Environ Microbiol 53(8): 1866-1871.

81. Lewis G, Schrire B, MacKinder B, Lock M (2005) Legumes of the world. Royal Botanical Gardens, Kew Publishing, ISBN 190034780 6, UK.

82. Luka EG, Yahaya H (2012) Perceived constraints to use of indigenous soil management practices among yam producers in Nasarawa state, Nigeria. J Sust Dev Afr 14(2): 1520- 5509.

83. Morales A, Garland JL, Lim DV (1996) Survival of potentially pathogenic human-associated bacteria in the rhizosphere of hydroponically grown wheat. FEMS Microb Ecol 20(3): 155-162.

84. Martínez-Romero E, Segovia L, Mercante FM, FrancoAA, Graham P, et al (1991) Rhizobium tropici, a novel species nodulating Phaseolus vulgaris L. beans and Leucaena sp. trees. Int J Syst Bacteriol 41(3): 417-426.

85. Mahmoud AHH, Elkotkat MBO, Omar MNA, Mostafa GA (2011) Activity of azotobactera nd azospirillumin the rhizosphere of onion plant agric chem. and biotech. Mansoura Univ 2(10): 229-238.

86. Roy P (2016) A comparative study of three rhizospheric bacteria belonging to different genera, co-infecting a leguminous. Plant J Investig Genomics 3(3): 00053.

87. Popelka C, Terryn N, Higgins T (2004) Gene technology for grain legumes: can it contribute to the food challenge in developing countries? Plant Science 167(2): 195-206.
88. Rivas R, Peix A, Mateos PF, Trujillo ME, Martinez-Molina E, et al. (2006) Biodiversity of populations of phosphate solubilizing rhizobia that nodulates chickpea in different spanish soils. Plant and soil 287(Suppl 1-2): 23-33.

89. Ribeiro RA, Martins TB, Ormeño-Orrillo E, Marçon Delamuta JR, Rogel MA, et al. (2015) Rhizobium ecuadorense sp. nov. an indigenous N2fixing symbiont of the Ecuadorian common bean (Phaseolus vulgaris L.) genetic pool. Int J Syst Evol Microbiol 65(9): 3162-3169.

90. Roesch LFW, Fulthorpe RR, Riva A (2007) Pyrosequencing enumerates and contrasts soil microbial diversity. ISME J 1(4): 283-290.

91. Sadowsky MJ, Tong Z, De Souza M, Wackett LP (1998) AtzC is a new member of the amidohydrolase protein superfamily and is homologous to other atrazine-metabolizing enzymes. Journal of Bacteriology 180(1):152-158.

92. Suckstorff I, Berg G (2003). Evidence for dose-dependent effects on plant growth by Stenotrophomonas strains from different origin J Appl. Microbiol 95(4): 656-663.

93. Singh S, Kapoor KK (1999) Inoculation with phosphate solubilizing microorganisms and a vesicular arbuscular mycorrhizal fungus improves dry matter yield and nutrient uptake by wheat grown in a sandy soil. Biol Fert Soils 28(2):pp.139-144.

94. Segovia L, Young JP, Martı́nez-Romero E (1993) Reclassification of American Rhizobium leguminosarum biovar phaseoli type I strains as Rhizobium etli sp. nov. Int J Syst Bacteriol 43(2): 374-377.

95. Stallknecht, Gilbert F (1997) New crop fact sheet. Teff. Hort.purdue.

96. Qiao YJ, Li ZZ, Wang X, Zhu B, Hu YG, et al. (2012) Effect of legume-cereal mixtures on the diversity of bacterial communities in the rhizosphere plant soil environ 58(4): 174-180.

97. Tewodros M, Asfaw K (2014) Indigenous knowledge and Evaluation of Enset (EnseteventricosumWelw.Cheesman) pests and diseases in Ojojia of Kembata-tembaro zone, South Ethiopia. Unique Res. J Agric Sci 2(1): 007-012.

98. Ulrich A, Klimke G, Wirth S (2008) Diversity and Activity of Cellulose Decomposing Bacteria, Isolated from a Sandy and a Loamy Soil afterLong-Term Manure Application. Microbiol. Ecol 55(3): 512-522.

99. Vessey JK (2003) Plant growth promoting rhizobacteria as biofertilizers. Plant Soil 255(2): 571-586.

100. Zeenat Wadhwa, Vivek Srivastava, Raj Rani, Tanvi, Kanchan Makkar, et al. (2017) Isolation and Characterization of Rhizobium from Chickpea (Cicer arietinum) Int J Curr Microbiol App Sci 6(11): 28802893.

\section{Your next submission with Juniper Publishers} will reach you the below assets
- Quality Editorial service

- Swift Peer Review

- Reprints availability

- E-prints Service

- Manuscript Podcast for convenient understanding

- Global attainment for your research

- Manuscript accessibility in different formats

( Pdf, E-pub, Full Text, Audio)

- Unceasing customer service

Track the below URL for one-step submission https://juniperpublishers.com/online-submission.php 